\title{
LIMITS OF JURISDICTION FOR DIVORCE UNDER THE BRUSSELS IIA REGULATION FROM THE CZECH PERSPECTIVE
}

\author{
ZUZANA FIŠEROVÁ*
}

\begin{abstract}
Jurisdiction for divorce in a marriage with an international element is in the Czech Republic governed primarily by “the Brussels IIa Regulation". There are, however, other legal sources on which Czech courts can base their jurisdiction. When a national court is seized with a cross-border divorce case, the first step is to establish or decline the jurisdiction. In purely intra-EU cases, the Brussels IIa Regulation is the only legal instrument that comes into play. If the case involves a third State, the jurisdiction can be based on rules contained in a specific bilateral international agreement or, the provision for residual jurisdiction in the Brussels IIa Regulation permitting, on the rules in the national legislation of private international law. Complex situations can occur, especially when the case presents several international elements, some related to EU Member State(s) and the others related to the third State(s). The jurisprudence developed by the CJEU to interpret the Brussels IIa Regulation is shedding light on some provisions thereof, although there are still several questions waiting to be answered, one of them being the autonomous EU interpretation of the term "marriage" in the context of the scope of the Regulation.
\end{abstract}

Keywords: marriage; divorce; Brussels IIa Regulation; jurisdiction; bilateral international agreement

DOI: $10.14712 / 23366478.2020 .35$

\section{INTRODUCTION}

The Czech Republic acceded to the European Union on the 1st of May 2004. Since then, EU legislation has been applicable on its territory. In the field of family law, accession brought to the Czech legal system the Brussels II Regulation ${ }^{1}$ which was soon replaced by the Council Regulation (EC) No 2201/2003 of 27 November 2003 concerning jurisdiction and the recognition and enforcement of judgments in matrimonial matters and the matters of parental responsibility, repealing Regulation (EC) No $1347 / 2000$ (hereinafter referred to as "the Brussels IIa Regulation" or "Regulation").

* Ph.D. candidate, Faculty of Law, Charles University, Prague. Director, International Department for Civil Matters, Ministry of Justice, Czech Republic.

1 Council Regulation (EC) No 1347/2000 of 29 May 2000 on jurisdiction and the recognition and enforcement of judgments in matrimonial matters and in matters of parental responsibility for children of both spouses. 
The Brussels IIa Regulation introduced several new concepts to the Czech doctrine of international family law: priority of EU rules over the national Private International Law $\mathrm{Act}^{2}$ (and, to some extent, over bilateral international treaties), multilateral rules for jurisdiction based primarily on habitual residence as the main connecting factor, unified rules for recognition (and enforcement) of judgments, integration of the Hague Convention of 25 October 1980 on the Civil aspects of international child abduction etc. Acceptance and proper understanding of the new Regulation and its mechanism by the judiciary and legal practitioners was not immediate. Today, however, the Brussels IIa Regulation presents an indisputable cornerstone of international procedural law in family matters.

This article tries to focus primarily on the rules on jurisdiction for divorce proceedings as applied by Czech courts. The main aim is to outline a picture of the legislative framework as well as of some practical issues the legal practice faces today when solving the question as to which court is competent to decide on a cross-border divorce case. The first chapter therefore describes different legal sources comprising competence rules and tries to clarify their interconnection; the second chapter concentrates on selected problems explicitly or implicitly related to jurisdiction.

\section{JURISDICTION FOR DIVORCE: SOURCES OF LAW IN THE CZECH CONTEXT}

There are three main legal sources (the Brussels IIa Regulation, Private International Law Act and bilateral agreements), each having a different material, geographical, temporal and, in some respect, personal scope. If a cross-border divorce case occurs, the first procedural step of the court seized is to establish its jurisdiction.

\subsection{BRUSSELS IIA REGULATION}

The substantive scope of the Regulation extends to "civil matters relating to $[\ldots]$ divorce, legal separation or marriage annulment" (Article 1a). The Regulation furthermore applies "in civil matters relating to [...] the attribution, exercise, delegation, restriction or termination of parental responsibility" (Article 1b). Substantive scope in matrimonial matters is further clarified in Recital 8 of the Regulation, which reads: "As regards judgments on divorce, legal separation or marriage annulment, this Regulation should apply only to the dissolution of matrimonial ties and should not deal with issues such as the grounds for divorce, property consequences of the marriage or any other ancillary measures." Concerning geographical scope, the Brussels IIa Regulation applies in all Member States of the EU with the exception of Denmark (see Recital 31). ${ }^{3}$

2 Act No. 91/2012 Coll., on Private International Law, replaced the former Act No. 97/1963 Coll. as of 1 January 2014.

3 Recital 31: Denmark, in accordance with Articles 1 and 2 of the Protocol on the position of Denmark annexed to the Treaty on European Union and the Treaty establishing the European Community, is not participating in the adoption of this Regulation and is therefore not bound by it nor subject to its application. 
As regards temporal scope, the Regulation in principle applies as of 1 March 2005 (see Article 72). As for the personal scope, the Regulation does not provide for any definition of terms such as "marriage" or "spouse" (see chapter 3.2. below), the latter being used in the text in a strictly gender-neutral way. In contrast to its predecessors, the Convention of 1998 and Brussels II Regulation No 1347/2000, "in the case of Brussels IIa Regulation the respondent is not required to have his/her domicile in a Member State, nor is there any other rule which defines the personal scope of application". 4

Even though the rules in Article 3 (general jurisdiction) provide for a large array of jurisdictions (there are seven different connecting factors), the Regulation does not formally allow for a choice of court. The introduction of a choice of court provision was considered in the preliminary discussions on the recast of the Brussels IIa Regulation. The proposal of the European Commission as well as the final text of the Regulation adopted in 2019 retained, however, the status quo as regards jurisdiction in matrimonial matters and concentrated mainly on parental responsibility. ${ }^{5}$ General jurisdiction rules are based primarily on habitual residence. Alternative connecting factors in Article 3 para. 1(a) are delimited as follows: i) common habitual residence of the spouses, ii) last common habitual residence if one spouse still resides there, iii) habitual residence of the respondent, iv) in the case of a joint application the habitual residence of either of the spouses, v) habitual residence of the applicant if he or she resided there for at least a year immediately before the application was made, or vi) habitual residence of the applicant if he or she resided there for at least six months immediately before the application was made and is either a national of the Member State in question or, in the case of the United Kingdom and Ireland, has his or her "domicile" there. This range is completed in Article 3 para. 1(b) by a connecting factor of a common nationality of the spouses or, in the case of the United Kingdom and Ireland, of their common "domicile". The rules on the jurisdiction for counterclaims (Article 4) and for the conversion of legal separation into divorce (Article 5) are only rarely applied in the Czech context. On the other hand, provisions on the exclusive nature of jurisdiction (Article 6) and on residual jurisdiction (Article 7) are of significant importance when one has to consider the relationship with national competence rules (see further).

\subsection{PRIVATE INTERNATIONAL LAW ACT (PILA)}

Private International Law Act No. 91/2012 (hereinafter referred to as "PILA") replaced the former act governing private international law as of 1 January 2014 together with the new Civil Code $^{6}$ and Business Corporation Act. ${ }^{7}$ Although the relationship between national competence rules and the rules on jurisdiction in the Brussels IIa Regulation were not altered, the content of the act changed considerably. The structure of the rules on jurisdiction in the new PILA are strongly influenced by the

4 MANKOWSKI, M. Brussels IIbis Regulation. Munich: Sellier, 2012, p. 89.

5 Recast of the Brussel IIa Regulation (Regulation (EU) 2019/1111 on jurisdiction, the recognition and enforcement of decisions in matrimonial matters and the matters of parental responsibility, and on international child abduction) will be applicable as of August 1, 2022.

6 Act No. 89/2012 Coll., Civil Code.

7 Act No. 90/2012 Coll., on Commercial Companies and Cooperatives (Business Corporation Act). 
Brussels IIa Regulation and by the fact that the latter is applicable even in cases with third States (i.e., States that are not members of the European Union). National competence rules can be invoked only if the Regulation allows for it by way of the Article 7 on residual jurisdiction. ${ }^{8}$

In this context, it is worth mentioning the importance of the Court of Justice of the European Union (hereinafter referred to as "CJEU" or "ECJ") case-law on residual jurisdiction embodied in Article 7 of the Brussels IIa Regulation. In its judgment C-68/079 of 29 November 2007, Kerstin Sundelind Lopez v. Miguel Enrique Lopez Lizazo, the ECJ ruled that "Articles 6 and 7 of the Brussels IIa Regulation are to be interpreted as meaning that where, in divorce proceedings, a respondent is not habitually resident in a Member State and is not a national of a Member State, the courts of a Member State cannot base their jurisdiction to hear the petition on their national law, if the courts of another Member State have jurisdiction under Article 3 of that regulation." If we observe the ruling through the Czech legal framework, we can draw the conclusion that the national rules on jurisdiction in PILA are applicable if, and only if, there is no competent court in any Member State of the EU based on Articles 3 to 6 of the Brussels IIa Regulation.

The substantive scope of PILA rules coincides with the substantive scope of the Brussels IIa Regulation as it is applicable not only to establish the jurisdiction for proceedings concerning the dissolution of a marriage (divorce) but also for the annulment of marriage and the designation of whether or not a marriage has been legally concluded. Concerning personal scope, the PILA provides for a definition of neither "marriage" nor "spouse". In contrast to the Brussels IIa Regulation, PILA comprises conflict-of-law rules ${ }^{10}$ to determine the applicable material law.

PILA establishes the competence of Czech courts for divorce proceedings in Section 47. The structure of the provision is twofold. The first part governs situations when at least one spouse has Czech nationality or when the defendant has habitual residence in the Czech Republic. The second part covers situations where both spouses are foreign nationals and the defendant has neither habitual residence in any EU Member State nor

\footnotetext{
8 Article 7 Residual jurisdiction.
}

1. Where no court of a Member State has jurisdiction pursuant to Articles 3, 4 and 5, jurisdiction shall be determined, in each Member State, by the laws of that State.

2. As against a respondent who is not habitually resident and is not either a national of a Member State or, in the case of the United Kingdom and Ireland, does not have his "domicile" within the territory of one of the latter Member States, any national of a Member State who is habitually resident within the territory of another Member State may, like the nationals of that State, avail himself of the rules of jurisdiction applicable in that State.

9 Before their separation, Mrs. Sundelind Lopez (Swedish national) and Mr. Lopez Lizazo (Cuban national) had their common habitual residence in France. Mr. Lopez Lizazo then left to live in Cuba. Mrs. Sundelind Lopez filed for divorce in Sweden. It was not disputed that the French courts had jurisdiction in accordance with Article 3/1a) of the Brussels IIa Regulation. The CJEU (ECJ) was asked whether the courts of a Member State could base their jurisdiction on national law "where the respondent in a case concerning divorce is neither resident in a Member State nor a citizen of a Member State, even though a court in another Member State may have jurisdiction by application of one of the rules on jurisdiction set out in Article 3 of the Regulation".

10 The Czech Republic is not bound by the Council Regulation (EU) No 1259/2010 of 20 December 2010 implementing enhanced cooperation in the area of the law applicable to divorce and legal separation (Rome III Regulation). 
the nationality of any EU Member State. The first situation allows any Czech court to establish its jurisdiction under the condition that an international treaty or a directly applicable EU regulation (i.e., the Brussels IIa Regulation) does not state otherwise. Establishing the jurisdiction of a Czech court if both spouses are foreigners and the defendant is neither the national of nor habitually resident in any EU Member State is possible only if i) both spouses had their habitual residence in the Czech Republic and the applicant still has his/her habitual residence in the Czech Republic, ${ }^{11}$ or ii) the applicant has his/her habitual residence in the Czech Republic and the second spouse has agreed with the motion, or iii) the applicant has his/her habitual residence in the Czech Republic and has had this residence for a period of at least one year directly prior to the submission of the motion. The choice of court is not possible under PILA rules.

\subsection{BILATERAL INTERNATIONAL AGREEMENTS}

As mentioned above, before the Brussels IIa Regulation became applicable in the Czech Republic, courts applied rules on jurisdiction contained either in the Private International Law Act or in bilateral agreements. With some exceptions, these bilateral agreements were concluded mainly in the 70's and 80 's, especially with countries of the former socialistic bloc, ${ }^{12}$ and they usually follow a similar pattern. These complex legal instruments may cover, among other issues, cross-border judicial cooperation in civil and criminal matters (including rules on the service of documents, taking of evidence, legalization of public documents etc.) as well as private and procedural international law issues such as jurisdiction, applicable law, and the recognition and enforcement of judicial decisions. The bilateral agreements are in principle still in force, however, between the EU Member States they have been in most parts superseded by EU legislation.

The typical structure of divorce rules in a bilateral agreement comprises both conflict-of-law rules on applicable law and jurisdiction, the latter derived either from the former or formulated independently. In all cases, the rules on jurisdiction are based on the nationality or residence (not usually on the habitual residence) of one or both of the parties. As the agreements regulate cooperation and legal issues between the two contracting States it is obvious that the concept of nationality and residence takes into account the nationality and residence of one or the other contracting State only. This attitude is easily compatible with the national PILA rules over which the agreement takes precedence. It could, however, be more intricate to accommodate with a multilateral instrument such as the Brussels IIa Regulation (see below).

The PILA rules as described above clearly define their subordination to the EU Regulation or international agreements. On the other hand, the relationship between bilateral international agreements with third States and the Brussels IIa Regulation is

11 It might seem that there is no difference between this provision and the second item in Article 3 para. 1(a) of the Brussels IIa Regulation. The PILA provision, however, does not operate with the "last" habitual residence, therefore the extent of such a provision is broader.

12 The Czech Republic (the former Czechoslovak Socialist Republic) concludes bilateral agreements for example with Romania, Hungary, Poland, ex-Yugoslavia, ex-Soviet Union etc. 
not delimited explicitly. The Regulation includes provisions that govern the relationship with international agreements (including bilateral) between Member States. According to Article 59, the Regulation shall for Member States of the EU supersede conventions existing at the time of entry into force of the Regulation, which have been concluded between two or more Member States and relate to matters governed by the Regulation. There is only one exception for Nordic countries. ${ }^{13}$

Even though the Brussels IIa Regulation does not have a specific provision on a relationship with existing international instruments concluded between a Member State and a third State, one can lean on the rules incorporated into more recent legislative acts such as the Maintenance Regulation ${ }^{14}$ or the Regulation on succession. ${ }^{15}$ The general principle can be described as follows: The EU Regulation shall not affect the application of bilateral or multilateral conventions and agreements to which one or more Member States are party at the time of adoption of the Regulation and which concern matters governed by the Regulation. Notwithstanding this principle, the EU Regulation shall, in relations between Member States, take precedence over the conventions and agreements which concern matters governed by the Regulation and to which Member States are party. ${ }^{16}$ The bilateral (or multilateral) conventions or agreements that are still applicable vis-à-vis third States have to be in line with the obligations of Member States under the Article 351 of the Treaty on the functioning of the EU ${ }^{17}$ (former Article 307 of the Treaty), especially to take all appropriate steps to eliminate possible incompatibilities.

Similarly to the Brussels IIa Regulation or PILA, bilateral agreements do not provide definitions of "marriage", "divorce", or "spouse". The temporal scope has to be analysed for each agreement separately. Due to the limited external competences of EU Member States, no bilateral agreement has been concluded or ratified since the accession of the Czech Republic to the EU.

13 Finland and Sweden have the option of declaring that the Convention of 6 February 1931 between Denmark, Finland, Iceland, Norway and Sweden comprising international private law provisions on marriage, adoption, and guardianship, together with the Final Protocol thereto, will apply, in whole or in part, in their mutual relations, in place of the rules of the Brussels IIa Regulation (see Article 59(2)).

14 Council Regulation (EC) No 4/2009 of 18 December 2008 on jurisdiction, applicable law, recognition and enforcement of decisions and cooperation in matters relating to maintenance obligations.

15 Regulation (EU) No 650/2012 of the European Parliament and of the Council of 4 July 2012 on jurisdiction, applicable law, recognition and enforcement of decisions and acceptance and enforcement of authentic instruments in matters of succession and on the creation of a European Certificate of Succession.

16 Conf. Article 69 of the Maintenance Regulation or Article 75 of the Regulation on succession.

17 Treaty on the Functioning of the European Union.

Article 351 (ex Article 307 TEC)

The rights and obligations arising from agreements concluded before 1 January 1958 or, for acceding States, before the date of their accession, between one or more Member States on the one hand, and one or more third countries on the other, shall not be affected by the provisions of the Treaties.

To the extent that such agreements are not compatible with the Treaties, the Member State or States concerned shall take all appropriate steps to eliminate the incompatibilities established. Member States shall, where necessary, assist each other to this end and shall, where appropriate, adopt a common attitude.

In applying the agreements referred to in the first paragraph, Member States shall take into account the fact that the advantages accorded under the Treaties by each Member State form an integral part of the establishment of the Union and are thereby inseparably linked with the creation of common institutions, the conferring of powers upon them and the granting of the same advantages by all the other Member States. 


\subsection{THE INTERPLAY OF THE THREE LEGAL SOURCES FOR JURISDICTION IN DIVORCE PROCEEDINGS}

Let us assume two situations before the Czech courts: First, the divorce of a mixed marriage of a Czech national and a German national, and second, the divorce of a mixed marriage of a Czech national and a Russian national. In the first case, the Czech court will ponder its jurisdiction automatically on the basis of the Brussels IIa Regulation, in the second case it is supposed to apply the bilateral agreement between the Czech Republic and the Russian Federation. ${ }^{18}$ This interpretation is perfectly straightforward if the (habitual) residence of the spouses "copies" the nationality. In other words, if in the first case the spouses have their habitual residence in (a) Member State(s) of the EU and in the second case their residence lies within one or both contracting parties of the agreement (the Czech Republic and/or the Russian Federation). What happens if the German citizen has his/her habitual residence in a third State, for instance in Russia? And, how will the situation of the second case be altered if the Russian citizen has his/her habitual residence in an EU Member State, for instance Germany? On which legal instruments will the Czech court base its consideration whether it is competent to decide on the case?

It seems that the first modified situation (a couple of Czech-German citizens, the latter having habitual residence in Russia) has a clear solution drawn from the rule in Article 6 (b) of the Brussels IIa Regulation (exclusive nature of jurisdiction). A spouse who is habitually resident in the territory of a Member State, or is a national of a Member State, may be sued in another Member State only in accordance with Articles 3, 4 and 5. It is questionable if the rules for residual jurisdiction in Article 7 (1) apply in the situation when no court of a Member State has jurisdiction (for instance because both the spouses have their habitual residence in Russia). Since the provision of Article 7 (1) refers only to Articles 3,4 and 5, it is not clear how to interpret the rule on the exclusive nature of jurisdiction in Article 6. In other words, if no court of any Member State has jurisdiction based on Articles 3 to 5 of the Regulation, can a claim against a German (or other EU) citizen be brought before a Czech court on the basis of national rules on jurisdiction by way of the application of provisions on residual jurisdiction in Article 7?

Although the answer is not clear from the linguistic interpretation of the text of the Regulation, the above-mentioned CJEU case-law (C-68/07) seems to allow for an affirmative conclusion, which is in line with the logic of Article 7 as well.

In the second modified case (a couple of Czech and Russian citizens, the latter having habitual residence in Germany) the situation seems rather complex as well. It has already been mentioned that there is a bilateral agreement between the Czech Republic and Russia, which provides rules on jurisdiction for a divorce. The question is whether we are still dealing with a bilateral Czech-Russian case. Or, due to the habitual residence of the Russian defendant in Germany, should the court omit the cross-border element based on nationality, give priority to the habitual residence of the defendant within the

18 International agreement between the Czechoslovak Socialist Republic and the Soviet Union on legal aid in civil, family and criminal matters, No. 95/1983 Coll. 
EU, consider it as a purely EU case, and establish or decline the jurisdiction only on the basis of the Brussels IIa Regulation?

The author of this article tends to answer the last question affirmatively and perceive the case primarily from the intra-EU perspective, even though the Brussels IIa Regulation itself and the subsequent jurisprudence of the CJEU (see next chapter) do not prioritize between nationality and habitual residence as connecting factors. It is possible to add another supporting argument: although the recognition of judgements is not further analysed in this text, it seems rather obvious that even for a third State national (a Russian citizen) habitually resident in a Member State (Germany) it may be more favourable to seek there the recognition of a divorce decision rendered and certified in compliance with the EU Regulation.

\section{SELECTED ISSUES INHERENT IN RULES ON JURISDICTION IN THE BRUSSELS IIA REGULATION}

\subsection{INTERNATIONAL ELEMENT IN DIVORCE PROCEEDINGS: NATIONALITY AND (HABITUAL) RESIDENCE}

Previous practical examples demonstrate that a case can contain more than one international element, the most important in matrimonial matters being the nationality and/or (habitual) residence of the spouses. "Habitual residence" is a connecting factor originally developed by the Hague Conference on Private International Law and systematically used in EU legislation. Contrary to the connecting factor of "nationality", it guarantees proximity to the life circumstances of the person concerned. Unfortunately, defining habitual residence of a person can be more cumbersome than determining his/ her nationality. Neither the modern Hague family law conventions, which employ the habitual residence as a connecting factor, nor EU regulations define it. ${ }^{19}$

PILA in its Section 47 bases the rules on jurisdiction on habitual residence and nationality. In bilateral agreements, however, the main connecting factors are nationality and (mere) residence. In all legal sources the (habitual) residence can be further qualified (common / last habitual residence, habitual residence for at least a year immediately before the application was made) or even combined with nationality (e.g., jurisdiction based on the habitual residence of the applicant if he/she resided there for at least six months immediately before the application was made and is either a national of the Member State in question or, in the case of the United Kingdom and Ireland, has his or her "domicile" there ${ }^{20}$ ).

The CJEU, safeguarding the autonomous interpretation of the EU law, has in past years developed a jurisprudence concerning the concept of habitual residence, mainly for the cases of parental responsibility. In matrimonial matters, one of the very first decisions was rendered in the case C-168/08 Laslo Hadadi (Hadady) v. Csilla Marta Mesko

19 For further reading: PFEIFFER, M. Kritérium obvyklého pobytu v mezinárodním právu soukromém. Praha: Leges, 2013.

20 Conf. Article 3 para. 1(a) sixth item of the Brussels IIa Regulation. 
(Judgment of 16 July 2009). ${ }^{21}$ The CJEU ruled that "Where the court of the Member State addressed must verify, [...], whether the court of the Member State of origin of a judgment would have had jurisdiction under Article 3(1)(b) of that regulation, the latter provision precludes the court of the Member State addressed from regarding spouses who each hold the nationality both of that State and of the Member State of origin as nationals only of the Member State addressed. That court must, on the contrary, take into account the fact that the spouses also hold the nationality of the Member State of origin and that, therefore, the courts of the latter could have had jurisdiction to hear the case." The CJEU further clarified that spouses who both possess the nationalities of the same two Member States may seize the court of the Member State of their choice.

The case-law is relevant from two perspectives. First, it gives a clear interpretation of the rules on jurisdiction in Article 3 of the Brussels IIa Regulation as to the equality of all connecting factors and the practical claimant's autonomy to decide which court to seize if the courts of more than one Member State are competent, despite the absence of any formal rules on choice of court. Second, it may collide with national rules on multiple nationality (citizenship).

PILA provides for a special rule for multiple or uncertain citizenship in its Section 28: "If an individual is a citizen of the Czech Republic in the appropriate period and if another State also considers the individual to be its citizen, the decisive citizenship will be that of the Czech Republic. If an individual is simultaneously a citizen of several foreign States, the appropriate citizenship will be decided according to the last acquired citizenship, provided that the individual's living situation does not significantly favour the citizenship of another State of which the individual is also a citizen. The citizenship of any such State will be decisive in such a case." Even though the attribution of citizenship and its conditions fall within the competence of the respective Member State, the interpretation of multiple citizenship (nationality) must be in conformity with EU law and CJEU jurisprudence. The author of this article concludes, therefore, that PILA rules cannot hamper the possibility of a party to the proceedings having more than one nationality to base the jurisdiction on either of them.

21 Two Hungarian nationals who married in Hungary in 1979 emigrated to France in 1980, where they subsequently resided. In 1985 they became naturalised French citizens. Mr. Hadadi instituted divorce proceedings on 23 February 2003 in Hungary, and Mrs. Hadadi instituted divorce proceedings in France on 19 February 2003. After the accession of Hungary to the EU on the 1st of May 2004, the Hungarian court granted the divorce on 4 May 2004. The French court dealing with divorce proceedings declared the proceedings inadmissible. Upon appeal by the (ex-)wife the Cour d'appel de Paris held that the Hungarian divorce decision could not be recognised in France. Mr. Hadadi appealed on a point of law to the Cour de cassation, reasoning that the Court of Appeal had rejected the recognition of the Hungarian decision solely on the basis of Article 3(1) a) of the Brussels IIa Regulation without having examined Article 3(1) b) of the Regulation. The French Court of Cassation referred the following questions to the CJEU: "1. Is Article 3(1)(b) [of Regulation No 2201/2003] to be interpreted as meaning that, in a situation where the spouses hold both the nationality of the State of the court seised and the nationality of another Member State of the European Union, the nationality of the State of the court seised must prevail? 2. If the answer to Question 1 is in the negative, is that provision to be interpreted as referring, in a situation where the spouses each hold dual nationality of the same two Member States, to the more effective of the two nationalities? 3. If the answer to Question 2 is in the negative, should it therefore be considered that that provision offers the spouses an additional option, allowing those spouses the choice of seising the courts of either of the two States of which they both hold the nationality?" 
The Brussels IIa Regulation applies "in matters relating to [...] divorce, legal separation or marriage annulment" but it does not contain any definition of "marriage" or of other terms used in Article 1(a). The situation has remained unchanged even after the adoption of several new EU regulations in the field of family law. Neither the recast of Brussels IIa Regulation nor the new Regulation on matrimonial property regimes ${ }^{22}$ contain any definition of "a marriage". There was an attempt to produce a definition of a "registered partnership" in the parallel Regulation on the property consequences of registered partnerships, ${ }^{23}$ although the very broad wording of the definition does not provide sufficient guidance for interpretation. In other words, the provision is completely silent as to whether partnerships covered by the Regulation concern exclusively same-sex couples or whether the scope can be extended to different-sex (non-marital) unions, too. ${ }^{24}$

The cardinal question in this context seems to be whether the rules on jurisdiction for divorce proceedings in the Brussels IIa Regulation apply equally to same-sex marriages bearing in mind that same-sex marriages only exist in a limited number of EU Member States (even though this number is growing) while other EU Member States allow only for same-sex registered partnerships. There is still a third category of EU Member States where same-sex partners are denied the opportunity to formalise their relationship in either way. So far, there is no common approach within the EU to the question of whether same-sex partners should be able to marry and whether the term marriage could include same-sex marriage. ${ }^{25}$ Some authors are of the opinion that when it comes to the term marriage in the Brussels IIa Regulation, an autonomous interpretation is required, i.e., the applicability of the Regulation to same-sex marriage cannot depend on the national law notion of the term marriage. Nonetheless, the different approaches to same-sex marriage in the EU play a role in the arguments exchanged between those who favour the applicability of the Regulation to same-sex marriage and those who argue against it. ${ }^{26}$ Despite of the requirement for uniform interpretation, concrete experience seems to

22 Council Regulation (EU) 2016/1103 of 24 June 2016 implementing enhanced cooperation in the area of jurisdiction, applicable law and the recognition and enforcement of decisions in matters of matrimonial property regimes.

23 Council Regulation (EU) 2016/1104 of 24 June 2016 implementing enhanced cooperation in the area of jurisdiction, applicable law and the recognition and enforcement of decisions in matters of the property consequences of registered partnerships.

24 See Article 3 (definitions): 'registered partnership' means the regime governing the shared life of two people which is provided for in law, the registration of which is mandatory under that law and which fulfils the legal formalities required by that law for its creation.

25 For further reading on the legal situation of same-sex couples in Europe: BOELE-WOELKI, K. FUCHS, A. Same-Sex Relationships and Beyond, Gender Matters in the EU. 3rd edition. Cambridge: Intersentia, 2017, or FUCHS, A. Registered partnership, same-sex marriage and children: crossing borders. Rivista di diritto internazionale private e processuale, 2016, No. 2.

26 Conf. Hirsch Juliane in Better Applying the EU Regulations on Family and Succession Law (ERA, Case study on divorce and maintenance obligations): "Those opposing the applicability of the Brussels IIa Regulation to same-sex marriage refer, inter alia, to the fact that at the time the Regulation was drafted only one EU Member State (the Netherlands) allowed same-sex marriage and that therefore clearly it was not intended that Brussels IIa would include same-sex marriage. Others argue that even if Brussels IIa was drafted at a time when same-sex marriage was not yet widely permitted, this is no argument against 
lead to the conclusion that the jurisdictions of each Member State address the absence of the definition of marriage through their national substantive law or, through the relevant applicable law.

Czech material law $^{27}$ provides the possibility to conclude a same-sex registered partnership, while same-sex marriages are neither permitted nor recognised (in principle). National material law is reflected in PILA in specific provisions on "the registered partnerships and similar relationships" (Section 67). According to PILA, Czech courts are entitled to rule on the annulment, invalidity, and non-existence of a registered partnership or a similar relationship if the registered partnership has been concluded in the Czech Republic or at least one of the partners is a citizen of the Czech Republic and has his or her habitual residence in the Czech Republic. Registered partnerships and similar relationships and their effects, the capacity to conclude them and their annulment, invalidity, and nonexistence are subject to the law of the State in which the registered partnership or similar relationship has been or was concluded. The same law also governs the regulation of the personal and property relations of the partners.

The question arises when a same-sex couple concludes a "marriage" in a foreign country that permits this kind of formalised union, and then one or both of the spouses seize a Czech court with a "divorce" motion. The court has to decide whether there is a marriage or a registered partnership or no formal bond at all. The situation might be even more ambiguous if the same-sex marriage concluded abroad was subsequently adapted and registered in the Czech Republic by the civil registry office as a "registered partnership". Presumably, there are two possible ways how to deal with such a case, neither of them being without difficulties.

One option is to treat the case as a marriage. This approach means that the court should give effects to the same-sex marriage concluded abroad and overcome the question of public policy. The public policy clause under PILA in Section 4 stipulates that "provisions of any foreign applicable law which is supposed to be used in accordance with the provisions of this act cannot be applied, if the effects of such application would clearly contravene public order. Likewise, it is not possible on the same grounds to recognise any foreign judgements, foreign court settlements, foreign notary or other public documents or foreign arbitration judgements or to execute a judicial cooperation request from abroad or to recognise any legal relations or any facts which have arisen abroad or according to a foreign law". In a very informal way, the author of this article inquired a group of Czech judges in order to establish whether the public policy clause could present an insurmountable obstacle to the recognition of the same-sex marriage concluded abroad simply for the sake of the admissibility of the divorce proceedings. Rather surprisingly, many voices claimed that there is no more room for the public poli-

its application to same-sex marriage today. The Regulation does not define 'marriage' and thus does not expressly exclude same-sex marriage. Furthermore, the rules of EU law must today be applied in a way that is compatible with the rights enshrined in the EU Charter of Fundamental Rights, and the Charter expressly prohibits any discrimination based on grounds of sex or sexual orientation (Article 21 (1) of the Charter). As said, the issue is not yet resolved, the Court of Justice of the EU (CJEU) has not yet had occasion to decide the matter and we might, for the time being, see different interpretations of the term 'marriage' in the Brussels IIa Regulation across Europe."

27 Act on the Registered Partnership, No. 115/2006 Coll. 
cy reservation as regards acceptance or even recognition of a same-sex marriage. If this approach prevails in the future, courts will establish their jurisdiction on the basis of the Brussels IIa Regulation similarly to the cases of different-sex marriages.

The other possible approach is to adapt the same-sex marriage to the circumstances of national material and administrative law and to deal with it as with a registered partnership. Even this option, however, has several hidden drawbacks. In such a case, the jurisdiction has to be established on the basis of the PILA rules. The first obstacle may be the necessary connection to the Czech territory as there is the condition for the partnership to be registered in the Czech Republic or the condition that at least one of the partners has Czech nationality and has habitual residence in the Czech Republic. Nonetheless, trickier is the interconnection between the jurisdiction and the conflict of laws rules. According to PILA, the law applicable for the dissolution of a registered partnership is the law of the State where the partnership was concluded. If the union was concluded under a foreign law as a "marriage", how would the Czech court apply the same material law in the proceedings for the dissolution of a "registered partnership"? Therefore, even this approach leads to similar difficulties as the first one, although at a later stage of the considerations.

\subsection{LIS PENDENS}

The analysis of the rules on jurisdiction would not be complete without a reflexion on the lis pendens. Each of the above-mentioned sources of law (the Brussels IIa Regulation, bilateral agreements, PILA) deals with this issue in a different way and sets up a specific set of rules.

The Brussels IIa Regulation provides for a rigorous system in Article 19 (Lis pendens and dependent actions) strictly prioritising the court first seized. "Where proceedings relating to divorce, legal separation or marriage annulment between the same parties are brought before courts of different Member States, the court second seised shall of its own motion stay its proceedings until such time as the jurisdiction of the court first seised is established." Once the jurisdiction of the court first seized is established, the court second seized shall automatically decline jurisdiction in favour of that court. This rule is similar to the provision enshrined in several bilateral agreements on legal aid, for instance in Article 18 of the agreement in force between the Czech Republic and the Russian Federation. Where proceedings on the same matter between the same participants have been commenced before courts in both contracting States and the jurisdiction is either based on the agreement or on the national rules of the contracting parties for matters that are not covered by the agreement, the court that was seized later shall stay the proceedings. Although the provisions seem perfectly straightforward, the practice may face some difficulties when establishing which court was seized first and when communicating the information to the court second seized.

The CJEU rendered a judgment of 5 October 2015 in the case A v B (C-489/14) ${ }^{28}$ where it ruled that in the case of judicial separation and divorce proceedings brought

28 French spouses, parents of two children, residing for years in the UK, separated in 2010. The husband brought proceedings for judicial separation in France, the wife filed a petition for divorce in the UK. 
between the same parties before the courts of two Member States, Article 19(1) and (3) of the Brussels IIa Regulation, "[...] must be interpreted as meaning that, in a situation such as that at issue in the main proceedings in which the proceedings before the court first seised in the first Member State expired after the second court in the second Member State was seised, the criteria for lis pendens are no longer fulfilled and, therefore, the jurisdiction of the court first seised must be regarded as not being established". In the case C-173/16 M.H. v. M.H. the CJEU provided the interpretation of Article $16^{29}$ and the moment when the proceeding are initiated if different procedural rules apply in the two respective Member States where courts have been seized with the similar case. According to the order rendered on 22 June 2016 Article 16(1)(a) of the Brussels IIa Regulation must be interpreted to the effect "that the 'time when the document instituting the proceedings or an equivalent document is lodged with the court', within the meaning of that provision, is the time when that document is lodged with the court concerned, even if under national law lodging that document does not of itself immediately initiate proceedings".

The rules on lis pendens in PILA are in contrast with the Brussels IIa Regulation and the general clause in bilateral agreements. PILA in Section 8(2) provides the Czech court later seized with the option (not the obligation) to suspend the proceedings if, and only if, several conditions are met. It explicitly says that proceedings initiated in a different State will not prevent the commencement of proceedings pertaining to the same matter between the same participants before a Czech court. If the proceedings in the Czech court commence later than the proceedings held in another State, the Czech court "may" suspend the proceedings in justified cases, if it can be expected that the foreign authority's judgement will be recognised in the Czech Republic. Particular attention should be paid to the fact that according to PILA the condition of reciprocity regarding the recognition of the respective foreign judgment is a conditio sine qua non for the application of the lis pendens clause.

\section{CONCLUSION}

Family law usually reflects cultural traditions of the country. Traditions, historical context, geographical situation and other specificities may have an impact on the national material and procedural laws as well as on the private international law rules of the respective country. They can equally influence judges and other legal practitioners when interpreting and applying national and international rules on jurisdiction and applicable law in their everyday practice. National legislation and jurisprudence

29 Article 16 (Seising of a Court)

1. A court shall be deemed to be seised:

(a) at the time when the document instituting the proceedings or an equivalent document is lodged with the court, provided that the applicant has not subsequently failed to take the steps he was required to take to have service effected on the respondent; or

(b) if the document has to be served before being lodged with the court, at the time when it is received by the authority responsible for service, provided that the applicant has not subsequently failed to take the steps he was required to take to have the document lodged with the court. 
proportionately affect the positions and mandate of a State when negotiating new legal instruments at the international level (European Union, Hague Conference on Private International Law etc.). As international family law is an area of law where achieving a consensus proves itself to be challenging, the European Union has repeatedly had recourse to alternative solutions in the form of "enhanced cooperation". 30

When a national court is seized with a cross-border divorce case, the first step is to establish or decline the jurisdiction. In purely intra-EU cases, the Brussels IIa Regulation is the one and only legal instrument that comes into play. If the case involves a third State, the jurisdiction can be based on rules contained in a specific bilateral international agreement or, if the provision for residual jurisdiction in the Brussels IIa Regulation permits, on the rules in the national legislation on private international law. Complex situations can occur, especially when the case presents several international elements, some of them related to the EU Member State(s), and others related to the third State(s). The jurisprudence of the CJEU developed to interpret the Brussels IIa Regulation is shedding light on some provisions thereof, although there are still several questions that waiting to be answered, among them the autonomous EU interpretation of "marriage" in the context of the scope of the Regulation.

Mgr. et Mgr. Zuzana Fišerová

International Department for Civil Matters, Ministry of Justice, Czech Republic

ZFiserova@msp.justice.cz

30 "Enhanced cooperation" is a procedure where a specific number of EU member states are allowed to establish advanced integration or cooperation in an area within EU structures but without the other members being directly involved. This procedure has been used so far in the fields of divorce law, EU patents, property regimes of international couples, and in the European Public Prosecutor Office. 